\title{
The Effect of School Principals Integrity, Communication Atmosphere, Discipline and Achievement Motivation on Teachers' Work Productivity at Public Vocational High School (SMK) in Padang
}

\author{
Ariswan' $^{1}$, Rusdinal $^{2}$, Muri Yusuf ${ }^{3}$, Gusril $^{4}$ \\ ${ }^{1234}$ Universitas Negeri Padang, Padang - Indonesia
}

\begin{abstract}
The phenomenon in the field illustrates the low productivity of teachers in assigning tasks. This research aims to reveal the influence of: (1) Integrity of principal and work discipline to motivation of teacher achievement in SMK, (2) Integrity of principal to teacher work discipline in SMK Negeri Kota Padang, (3) Integrity of principal, work discipline and motivation achievement on teacher work productivity in SMK Negeri Kota Padang. The sample of the study amounted to 266 people. The research data was collected by Likert scale model questionnaire. Data were analyzed by moderation variable path analysis technique. The result of the research shows that: (1) There is direct and indirect influence significantly Integrity of school principal and work discipline of teacher toward achievement motivation, (2) There is direct and indirect influence significantly Integrity of principal to work discipline (3) There is direct influence and not significantly the integrity of the principal, work discipline and achievement motivation affect the productivity of teachers work.
\end{abstract}

Keywords: integrity, discipline, motivation and productivity

\section{Introduction}

Vocational Secondary School (SMK) as a form of vocational education unit as defined in the explanation of Article 15 of Law no. 20 of 2003 on SISDIKNAS, is a secondary education that prepares students primarily to become middle-class workers in a particular field. Substance or material taught in SMK is presented in the form of various competencies that are considered important and necessary for the learner in living the life according to his era. Vocational education aims to equip students to have behavioral competence in a particular vocational field so that the concerned able to work (have a 
performance) for the future and his nation. Learners are equipped with knowledge of theory and practical skills, as well as social patterns and behavior and national insights. (Schippers, 1993). Vocational education equips students with theoretical knowledge and practical skills, as well as social patterns and behavior and national insights.

The specific objectives of Vocational High School are: (1) preparing students to become productive human beings, able to work independently, filling job vacancies in the business world and industry as middle-level workforce in accordance with competence in the chosen skill program; (2) prepare learners to be able to choose a career, tenacious and persistent in competence, adapt in the work environment, and develop a professional attitude in the field of expertise of interest; (3) equip students with science, technology, and arts, to be able to develop themselves in the future either independently or through higher education and (4) equip learners with competencies appropriate to the chosen skill program.

Therefore, to achieve the general goals as well as the special purpose of the vocational high schools, it is necessary to have qualified educators and qualified personnel, supportive learning processes and methods, standardized assessment standards, adequate infrastructure, adequate operational cost of education and good management.

According to Law No. 20 of 2003 Article 1 Paragraph 6, it is explained that the educator is a qualified educator who is a teacher, lecturer, counselor, pamong learn, widyaiswara, tutor, instructor, facilitator, and other designation in accordance with the specificity, and participate in the provision of education, while in Article 1 paragraph 5 also explained that the educational staff is a member of society who devoted themselves and appointed to support the implementation of education.

Educators and educational personnel are entitled to adequate and adequate welfare income and welfare, an appropriate award of duties and work performance, and career coaching according to the demands of professional quality development. Educators in this case teachers, occupy a strategic position to realize all these expectations and goals, because teachers as educators who are directly involved in the activities of the learning process in the classroom and the entire process of education in school. Teachers are required to have academic qualifications, competencies, educator certificates, physical and spiritual health, and have the ability to realize the goals of national education. If a number of requirements are met, then its role will be able to determine organizational productivity retreat. Research Tolla (1991) reports that teacher work productivity is a comparison between the principal's leadership and maximizing teacher potential and the teacher's own ability

To improve and develop teacher work productivity, the government has undertaken various efforts as outlined through various activities, among others; (1) improving the competence of teachers' expertise in the field. The activities are training on the development of skills and knowledge, training of learning media development, class action research workshops (PTK), expert competence workshops, competency test assessors or work place assessors (WPA), teacher performance appraisal assessment (PKG) national and training and become professional teachers and other activities. (2) improving the academic qualifications of teachers and employees to meet the demands of regulation of academic requirements of teachers and professional employees. The activity 
is to give an opportunity to the teacher who has not reached the academic qualification of S1 to continue his study with the encouragement and assistance in the form of scholarship, because this is the mandate of the Law of teachers and lecturers number 14 year 2005, as well as for sebahagian teachers who want to continue their education to Magister level. The government also promotes teachers through teacher certification programs to become professional teachers through the channels set forth in article 3 of PERMENDIKBUD No. 62 of 2013 on teacher certification of teacher training and education programs (PLPG) or through teacher professional education (PPG) or through undergraduate programs education with additional authority (SKKT) from the college appointed by the education minister. It is infectious to the welfare of teachers with the receipt of teacher certification money for the basic salary. On the other hand, the government through the ministry of education has made efforts to make improvements and curriculum development both the education unit level curriculum (KTSP) and the 2013 curriculum for piloting schools. The government also conducts the development of teaching system and strengthening teacher competence through education and training, upgrading, seminar, research and scientific writing. This is done so that teachers are more professional, because the teacher is a very decisive element in advancing education

Although there have been many programs and efforts undertaken by the government in advancing education, but the results obtained have not been maximized. This can be seen from the expression of dissatisfaction of education stakeholder to teacher work productivity. From observations made in several SMK Negeri Kota Padang and interviews with school supervisors, there are still found teachers who do not have complete and correct teaching tools, have not taught in accordance with process standards, have not mastered the material, methods and models and modern learning strategies, has not been able to use IT, has not carried out a standard assessment, has not carried out analysis on student evaluation results, has not followed up on the results of evalution analysis in the form of improvement and financing.

In the field of discipline in carrying out the task is still found a teacher who came late to school and also late to the classroom, there are even teachers who do not attend the time of teaching in the classroom without any substitute teacher which resulted in the learning process is not running properly. There are also teachers who come only during teaching hours and then go home and there is no task to guide students. There are also teachers who are not good relationships and peer communication so that the atmosphere is less comfortable and harmonious in the environment of fellow teachers, instead there is a group of teachers who pros and cons menacing togetherness. The majority of teachers are not motivated to develop professions such as seminars, scientific discussions, book writing, teaching materials, magazines, classroom action research (PTK), school action research (PTS), Best Practices, Journals and crafting kridit figures for promotion. On the other hand, the principal lacks integrity values such as honesty in saying and doing, keeping what he promised, being open in preparing and using school plans and activities (RAKS), having a vision and mission oriented forward, mastering the competencies that become reference for teachers

Based on data obtained from the education office of Padang city that; (1) In 2013/2014, there is no teacher of SMK Kota Padang who fulfill the requirement to be an achieving teacher of West Sumatera Province, (2) Teacher who has been graduated level IV / b 
upwards only 24 people, from total teachers 795 people, 3) The academic qualification of the new S.2 education level is 120 people from 795 teachers, (4) The average score of teacher performance appraisal result (PKG) conducted by PKG assessor is 45 out of 56, 5) teachers who have done classroom action research (PTK) and write new Journals 46 teachers from 795 teachers, (6) Average results obtained National Examination level SMK Kota Padang in the year 2013 only reached 6.54. From the ideal value of 7.00, (7) SMK graduates who work independently and absorbed the business world and industry on average only $30 \%$ of the total graduates, (8) SMK graduates received in state universities in the city of Padang just $10 \%$.

The above conditions is expected to reflect the productivity of teachers in the environment SMK Negeri Kota Padang as a whole. The low work productivity of teachers is thought to be strongly related to the principal leadership integrity variables, teacher achievement motivation, teacher work discipline, and communication climate in schools. If this is left it will bring a negative impact on the productivity of teachers in SMK Negeri Kota Padang.Berdasarkan symptoms that occur then it is necessary to assess what factors that affect the productivity of teachers work. This study is expected to produce intelligent solutions as a recommendation to establish preventive and corrective policies on the quality of schools in the future especially in the environment of public vocational high school (SMKN) Kota Padang.

Teachers as the spearhead of education in schools should understand and realize that many people are lending their hope to them in order to develop the potential of learners. Therefore the teacher must do the job perfectly as a professional teacher. One of the factors that really need to be a joint priority for education marwah is to improve teacher work productivity.

\section{Method}

This study aims to be able to know the influence between exogenous variable Principal Integrity (X1) and Communication Climate (X2), with endogenous variable that is Work Discipline (Y1), Achievement Motivation (Y2) and Teacher Work Productivity SMKN Kota Padang (Z). This study is also inferential, meaning that research results can predict the trend that will occur. This research was conducted in all SMK Negeri that exist in Padang City that is as much as 10 SMKN. The subject of this research is teachers of SMKN Kota Padang. The study period is planned for a maximum of six months. The population of this study are all teachers of SMK Negeri Kota Padang with the status of Civil Servants (PNS) at least one year and still actively teaching. Determination of civil servants as a population is because it is considered already have experience in teaching and have a bond service. Based on preliminary studies that have been done, the population is 795 people. The sample in this study amounted to 266 people.

Data on the five variables in this study, both exogenous variables (X1 and $\mathrm{X} 2)$ as well as endogenous variables ( $\mathrm{Y} 1, \mathrm{Y} 2$, and $\mathrm{Z}$ ), were collected using a Likert scale model questionnaire. By translating alternative responses in the form of continuum in the form of opinion (opinion) by using alternatives: Always (SL), Frequently (SR), Sometimes (KD), Rarely (JR), and Never (TP). respondents were given weight with score 5, 4, 3, 2, and 1, if positive statement and for negative statement then given weight of $1,2,3,4$, and 5. Data collecting done by giving questionnaire of principal integrity, achievement, work 
discipline, communication climate and work productivity teacher SMNKKota Padang. Implementation 2 months after trial done, by taking questionnaire data. Data analysis uses descriptive data, requirements testing and hypothesis testing.

\section{Result and Discussion}

Based on the results of the data analysis done, it can be described as follows: the integrity of the principal directly affects the teacher's work discipline, principal integrity affects indirectly the productivity of teachers, the integrity of the principal indirectly influences the teacher's achievement motivation, the communication climate directly affects the discipline of teachers work, communication climate effect on teacher productivity SMK Negeri Kota Padang, work discipline has an effect directly on teacher achievement motivation in SMK Negeri Kota Padang, achievement motivation effect on teacher work productivity at SMK Negeri Kota Padang, principal integrity affects achievement motivation through teacher work discipline, principal integrity influences the achievement motivation through teacher work discipline in SMK, the communication climate influences the achievement motivation through teacher work discipline in SMK Negeri Kota Padang, climate of communication effect on work productivity through teacher work discipline in SMK Negeri Kota Padang, principal integrity influences on work productivity through teacher achievement motivation in SMK Negeri Kota Padang, climate of communication influence on work productivity through teacher achievement motivation in SMK Negeri Kota Padang, work discipline indirectly affect productivity through achievement motivation, the integrity of the principal directly influences work productivity through teacher work discipline in SMK Negeri Kota Padang, climate of communication influence on work productivity through work discipline and motivation of teacher achievement in SMK Negeri Kota Padang.

The result of the research shows that: (1) There is direct and indirect influence significantly Integrity of school principal and work discipline of teacher toward achievement motivation, (2) There is direct and indirect influence significantly Integrity of principal to work discipline (3) There is direct influence and not significantly the integrity of the principal, work discipline and achievement motivation affect the productivity of teachers work. According to Harsey and Blanchard (2005: 184) say the level of formal education will affect the ability and motivation of achievement. Experience is the best educator who will guide learners in the learning process. Experienced people will always provide guidance to people who do not have experience, so the work can be done well and can also provide motivation to learn to learners to diligently learn. Rosidah (2009: 290), discipline is a form of self-control of employees / teachers and the implementation of a regular and show the level of seriousness of work teams within an organization. Discipline is very important in the effort to ensure the maintenance of order and smooth implementation of each task, without the high discipline to make teacher work productivity declining.

Teacher work productivity is the potential or power generated by teachers who are used maximally, to achieve output (output) more, creative, and generate profit or usefulness. Next I.B. Wursanto (1978: 150) says that work productivity is based on factors such as: a) high discipline, b) enthusiasm, c) high loyalty, d) fulfillment of physical needs, 
e) creativity and high initiative. Principal integrity that is done consistently by instilling integrity values in management and leadership in schools is expected to have a direct effect on teacher work productivity. Thus it becomes increasingly clear that the principal's integrity determines the productivity of teachers in carrying out the main tasks and functions as teachers who have poured the government in the regulation.

\section{Conclusion}

The conclusion of the research result shows that (1) there is direct and indirect influence significantly Integrity of principal and teacher work discipline to achievement motivation, (2) There is direct and indirect influence significantly Integrity of principal to work discipline (3) directly and indirectly significantly the integrity of the principal, work discipline and achievement motivation affect the productivity of teachers work

\section{References}

Arikunto, S. (2002). Prosedur Penelitian, Suatu Pendekatan Praktek. Jakarta: PT Rineka Cipta. Arikunto, Suharsimi. (1990). Prosedur Penelitian Suatu Pendekatan Praktek. Jakarta: Bina Aksara.

Bangun, Wilson. (2012). Manajemen Sumber Daya Manusia. Erlangga:Jakarta

Bertens, K. (1997). Etika. Jakarta: Gramedia Pustaka Utama.

Bernadin, J.H. Russell, A.J. (1998). Human Resource Management: an experiental approach. Singapure: A division of the mc graw hill company.

Bacal, Robert. (2001). Performance Management. Jakarta: PT Gramedia Pustaka Utama.

Becker, Thomas. (2001). Integrity in Organizations, USA: Internet.

Bafadal, I. (2003). Peningkatan Profesionalisme Guru Sekolah Dasar. Jakarta: Bumi Aksara.

Danim, Sudarwan. (2004). Motivasi, Kepemimpinan, dan Efektifitas Kelompok. PT Rineka Cipta. Jakarta.

De Porter, Bobbi and Mike Hemacki. (2000). Quantum Learning. Diterjemahkah oleh Alwiyah Abdurrahman, Bandung: Kaifa.

Dessler, Gary. (2004). Manajemen Sumber Daya Manusia.Edisi ke-9. Jilid 1. Jakarta: PT. Indeks kelompok Gramedia.

Gellerman, Saul W. (2000). Motivation and Productivity. Bombay: D.B. Taraporevala Sons.

Gaspersz, Vincent. (2001). Total Quality Management. Jakarta : PT Gramedia Pustaka Utama.

Gea, Antonius, dkk. (2002). Character Building I: Relasi dengan Diri Sendiri. Edisi Revisi. Jakarta: Gramedia Pustaka Utama.

Ghiselli, E.E., \& Brown, C.W. (2002). Personal and Industrial psychology, Mc Grow Hill, New York.

Maxwell, Jhon. (1995). Mengembangkan Kepemimpinan di dalam Diri Anda, Jakarta: Binarupa Aksara.

Maya. H. (2012). Kesalahan-kesalahan Umum Kepala Sekolah dalam Mengelola Pendidikan. Buku Biru. Jogjakarta. 
Milton. CR. (1981). Human Behavior in Organization Three Levels of Behavior. New York: Englewood Cliff, Prestice-Hall Inc.

Miftah, Thoha, (2008). Perilaku Organisasi: Konsep Dasar dan Aplikasinya. Jakarta: PT. Raja Grafindo Persada.

Munandar, Utami. (2009). Pengembangan Kreativitas Anak Berbakat Jakarta :PT. Rineka Cipta.

Mulyasa, E.. (2003). Manajemen Berbasis Sekolah. Bandung : Remaja Rosdakarya.

Robins, Stephen. P. (2000), Prilaku Organisasi, Konsep, Kontroversi, Aplikasi, (Terjemahan Oleh Hadyana Pujatmika) Jakarta: Prenhallindo

Robins, Stephen. P. (2003), Teori Organisasi: Struktur, Desain dan Aplikasi, Terjemahan Jusuf Udya, Jakarta : PT Arcan.

Rathel, Jeanna Marie; Drasgow, Erik; Christle, Christine C. (2008). "Effects of Supervisor Performance Feedback on Increasing Preservice Teacher's Positive Communication Behaviors with Students with Emotional and Behavioral Disorders". Journal of Emotional and Behaviors Disorders; jun 2008; 16,2, page 67; access 1 januari 2014.

Riduan. (2010). Cara Menggunakan dan Memaknai Path Analysis. Bandung: Alfabeta

Rosidah, Ambar Teguh Sulistiyani. (2009). Manajemen Sumber Daya Manusia : Konsep Teori dan Pengembangan dalam Konteks Organisasi Publik. Graha Ilmu: Yogyakarta. 